\title{
BACTERIOLOGICAL STUDIES ON AEROMONAS INFECTIONS OF NILE TILAPIA (OREOCHROMIS NILOTICUS ) IN FISH FARMS IN ALEXANDRIA GOVERNORATE .
}

\author{
OLA .A . BASHA \\ ANIMAL HEALTH RESEARCH INSTITUTE \\ ALEXANDRIA BRANCH .BACTERIOLOGY DEPT.
}

\section{SUMMARY}

A history of sever mortalities and morbidities among cultured Oreochromis niloticus in many different freshwater fish farms in Alexandria province were reported.

Clinical observation, postmortem changes as well as bacteriological isolation and identification revealed the presence of Aeromonas hydrophila in $60 \%$ of the examined fish samples .

Both intramuscular and intraperitoneal inoculation of Aeromonas hydrophila in 20 apparently healthy Oreochromis niloticus fish induced the previously observed clinical signs and re-isolation of the injected pathogen were done . isolated Aeromonas hydrophila were found to be highly sensitive to Oxytetracyclin and sulphamerazine .

\section{INTRODUCTION}

Aeromonas species has long been recognized as a pathogen of fish and frogs ( Popoff,1984, Son et al ., 1997 and Lehane and Rawlin , 2000 ). Aeromonas hydrophila occurs widely in nature, in water (Picard et al ., 1983 and Kompanets et al ., 1992 ), in milk ( Nagah , 1991 ), in meat (Ozbas et al ., 1996 ) and in human . Aeromonas causes gastroenteritis with sever human diarrhea (Millership et al ., 1983 and Buchanan and Palumbo , 1985 ) In fish Aeromonas hydrophila consists of a complex of disease organisms associated with bacterial haemorrhagic septicaemia ( Trust et al ., 1974)

Aeromonas is one of the most serious and frequently encountered pathogens of fish in warm-water aquacuture throughout the world. Aeromonas species have 
Implicated as the causative agents of red mouth disease of fish, intestinal dropsy of carp and septicaemia in warm water fish (Mayer ,1970, Snieszko and Bullock, 1974 , Essa et al ., 1985, Shahat and Hameda , 2000 and Samaha et al. , 2004 ). McGary et al . (1990) isolated species of Aeromonas and Vibrio from ulcerative disease syndrome of Florida fish in U. S. A . .

Several biochemical properties and virulence factors such as, protease , hemolysins, enterotoxins, dermonecrotic factors have been reported as potential indicators of pathogenicity in Aeromonas hydrophila. Allan and Stevenson (1981) reported that the toxic fraction of extracellular products is associated with hemolytic activity, while Kanai and Wakabayashi (1984 ) considered that protease's were the main virulence factors implicated in the pathological effects produced by culture filtrates . In addition, Norman (1988) reported that severe mortalities, endotoxic shock and morbidities among cultured fish had been occurred due to lipopolysacharide of the Aeromonas hydrophila cell wall. On the other hand, Lallier et al . (1984) concluded that undefined dermo-necrotic factors present in the extracellular products of Aeromonas hydrophila were responsible for fish mortality .

The present study was carried out to explore and document Aeromonas infections among cultured Oreochromis niloticus from farms in Alexandria province . Moreover the biochemical character of organisms and trials to induce experimental infection and detection of drug of choice for the treatment were considered .

\section{MATERIALS AND METHODS}

Sample collection : A total numbers of 100 moribund Oreochromis niloticus (100 g mean weight ) were collected alive from fish farms near Mariout lake, placed in plastic bags filled with water and air and transported to laboratory without delay. The samples were subjected to clinical observation and postmortem examination according to method described by Amlacher (1970) and Schaperclaus et al . (1992)for naturally and expermintally infected fish . Fish were observed for any gross lesions and abnormalities including haemorrhages, skin ulceration, fin erosions and abdominal distension . 


\section{Bacterilogical examination :}

Samples were taken aseptically from skin lesion, muscles, kidney , spleen, liver and intestine, about one gram from tissues and saline was streaked on Rimler - shotts media , nutrient agar and MacConkey's agar. After 24 hours of incubation at $30^{\circ} \mathrm{C}$, the plates of Rimler -shotts were examined for the presence of yellow orange colonies ( the specific colonies of Aeromonas as stated by Rimler and shotts , 1973 ) . Colonies from nutrient agar were picked up and transferred to nutrient agar slant for further identification . Gram stain and morphology of colonial appearance were reported with identification by biochemical tests which were done ( according to Cruickshank et al . (1975) and Lennette et $\underline{\text { al }}$. (1980).

\section{Pathogenicity test :}

The recovered bacterial isolates were examined for its ability to produce the disease in apparently healthy Oreochromis niloticus under experimental condition . 40 fish with an average weight $50 \mathrm{~g} \pm(1 \%)$ were divided to four groups and each group was kept in a well prepared glass aquarium (110x 40x $50 \mathrm{~cm}$ ) equipped with aeration and supplied with dechlorenated tap water. The water temperature in the aquarium was thermostatically adjusted to $28^{\circ} \mathrm{C}$. Fish were adapted for one week before starting the inoculation . The first group was inoculated intramuscularly (I /M ) below the dorsal fin with $0.5 \mathrm{ml}$ of suspension of Aeromonas hydrophila that contained $3 \times 10^{7} \mathrm{cfu}$ this was done by djusting the optical density to 0.3 at a wave - length 435 um by using spectrophotometer (Spectronic 20 , Bausch \&Lomb), while the second group was inoculated intraperitoneally ( I / P ) with the same dose. The third and fourth groups were left as controls and injected with $0.5 \mathrm{ml}$ sterile broth I / M and I / P respectively. All groups were observed daily for 2 weeks for clinical signs and any pathologic lesions and abnormalities .

Reisolation of the injected bacteria were done on Rimler - shotts media (shotts and Rimler, 1973 ).

\section{Sensitivity test :}

The antibiograms of the isolated pathogen were done using the disc diffusion method of Bauer et al . (1966). The interpretation of zones of inhibition were estimated according to the limits given by Finegold and Martin (1982) and Bio - Merieux (1984). Different antibiotic discs were used such as Oxytetracyclin , Ampicilline, Streptomycin, Penicillin, Neomycin, Erythromycin, Sulphamerazine and Chloramphenicol . 


\section{RESULTS}

The clinical signs and postmortem findings of diseased fish were characterized by erythema in the mouth, base of the fins and around the anus as well as exophthalmia. Affected fish showed congestion and petichial haemorrhage in the internal organs as well as erythema in the intestine with bloody mucous. The bacteriological examination revealed that Aeromonas hydrophila could be isolated from 60 out of 100 diseased fish samples examined ( $60 \%$ ). The organisms were a Gram negative, motile rod that gave round colonies ( $2-3 \mathrm{~mm}$ in diameter), and yellow- orange in colour on Rimler-shotts medium . Isolates showed beta hemolytic activity on blood agar . The morphological and biochemical characteristics of Aeromonas isolates are illustrated in Table 1 .

The I / M infected fish showed the same clinical signs and postmortem lesions that observed in natural infection with $70 \%$ mortality rate, while, the I / P infection revealed erythema at the site of injection with congestion in the internal organs and with $50 \%$ mortality. Aeromonas hydrophila were re-isolated from liver, kidney and spleen of all freshly dead and clinically diseased injected fish. No mortality and clinical signs were observed in control fish. The mortality rate, dose and route of inoculation, and time of death / day post- inoculation are described in Table 2 .

The result of drug sensitivity were summarized in Table 3 .From such table we can notice that Aeromonas hydrophila were sensitive to Oxytetracycline and Sulphamerazine .

\section{DISCUSSION}

Fish farming for food has grown rapidly in the past 30 years. The incidence of disease outbreaks among cultured fish has also increased. One of the common fish bacterial disease is the motile Aeromonas Septicaemia which caused by Aeromonas hydrophila. It appears that once the infection is established, a rapid growth of the bacteria and elaboration of its toxic products may cause systemic damage which lead to death (Brenden and Huizinga , 1986). This conclusion is forcly supported by the present investigation as the infection in the cultured Oreochromis niloticus spreads quickly and the mortality rate reach $60 \%$ within few days . On the other hand, El - shaboury, (1998) recorded an outbreak of infection in Oreochromis niloticus caused by Aeromonas hydrophila with $100 \%$ mortality. The 
differances in mortalities may be attributed to the type of fish and the culturing condition of fish, handling, crowding, as well as abrasion of surfaces increasing the risk of damage. The clinical signs and postmortem examination of the cultured naturally infected Oreochromis niloticus in the present study nearly simulate the results given by Mayer, (1970), Scheider and Nicholson , (1980), Essa et al .,(1985 ), Grizzle and Kiryu , (1993 ) and Shahat and Hamoda , (2000) .

Snieszko and Bullock, (1974) and Boira (1996) recorded that the disease is not a simple result of contact between host and pathogen. It was a complex interaction between host, pathogen and environment which played as an important stress factor for the occurance of infection by Aeromonas hydrophila. These enviromental factors included high temprature and humidity, waste products and organic matter, and long transportation . Nearly all these factors were present in the area of cultured fish farms around Marout lake and these predisposing factors may increase the susceptability of fish to infection. As shown in Table 2, the I / M inoculation of Aeromonas hydrophila in experimental fishes nearly showed similar clinical signs and postmortem lesions like those observed in natural infection. The mortalities were 50 and $70 \%$ in Oreochromis niloticus followed I / P and I / M injection respectively as well as the re-isolation of the Aeromonas hydrophila from these fish indicating that these organisms caused the disease. The I/ M route was more effective than I / P route. Similar findings were observed by Essa et al . ( 1991 ). The pathogenicity of Aeromonas hydrophila to fish was attributed to many virulente factors such as proteases and haemolysin. Soluman , (1988) and Coles et al ., (1969), reported that the virulent strains of Aeromonas hydrophila were able to produce enzyme capable of lysing Staphylococcus cells . while Kou ( 1972 ) found that the virulent strains produce proteolytic enzymes. Moreover, Wakabayashi et al . (1981) reported that Aeromonas hydrophila produce extracellular enzymes, cytotoxins and haemolysins. The result of drug sensitivity proved that, the isolated Aeromonas hydrophila were highly sensitive to Oxytetracycline and Sulphamerazine. These results are in agreement with those reported by Neumann and Polger (1979) and Essa et $\underline{\text { al }}$. (1991) . 
Table 1 : Morphological and biochemical characteristics of Aeromonas hydrophila isolated from Oreochromis niloticus .

\begin{tabular}{|l|l|}
\hline \multicolumn{1}{|c|}{ Test } & Results \\
\hline Gram stain & $-\mathrm{ve}$ \\
Motility & $+\mathrm{ve}$ \\
Arginine dehydrolase & $+\mathrm{ve}$ \\
Indole production & $+\mathrm{ve}$ \\
Oxidase & $+\mathrm{ve}$ \\
Catalase & $+\mathrm{ve}$ \\
Nitrate reduction & $+\mathrm{ve}$ \\
Gelatine hydrolysis & $+\mathrm{ve}$ \\
Beta-galactosidase & $+\mathrm{ve}$ \\
Fermentation of Glucose & $+\mathrm{ve}$ \\
Fermentation of Mannitol & $+\mathrm{ve}$ \\
Fermentation of Sucrose & $+\mathrm{ve}$ \\
Ornithin decarboxylase & $-\mathrm{ve}$ \\
H2S production & $-\mathrm{ve}$ \\
Urease production & $-\mathrm{ve}$ \\
Tryptophane deaminase & $-\mathrm{ve}$ \\
Vogus - proskauer production & -ve \\
Fermentation of Melobiose & Fermentation of Inositol \\
Fermentation of Sorbitol & \\
\hline
\end{tabular}


Table 2 : Pathogenicity of isolated Aeromonas hydrophila in healthy Oreochromis niloticus .

\begin{tabular}{|c|c|c|c|c|c|c|}
\hline $\begin{array}{l}\text { Fish } \\
\text { group }\end{array}$ & $\begin{array}{l}\text { Number } \\
\text { of } \\
\text { Inoculated } \\
\text { fish }\end{array}$ & $\begin{array}{l}\text { Routes of } \\
\text { inoculation }\end{array}$ & $\begin{array}{l}\text { Dose } \\
\text { per } \\
\text { fish }\end{array}$ & $\begin{array}{l}\text { Time of } \\
\text { death } \\
1 \text { day } \\
\text { inoculation }\end{array}$ & $\begin{array}{l}\text { Number } \\
\text { of dead } \\
\text { fish }\end{array}$ & $\%$ \\
\hline 1 & 10 & $\mathrm{I} / \mathrm{M}$ & $\begin{array}{l}0.5 \mathrm{ml} \\
3 \times 10^{7}\end{array}$ & $3-6$ & 7 & $70 \%$ \\
\hline 2 & 10 & $\mathrm{I} / \mathrm{P}$ & $\begin{array}{l}0.5 \mathrm{ml} \\
3 \times 10^{7}\end{array}$ & $2-4$ & 5 & $50 \%$ \\
\hline $\begin{array}{c}3 \\
\text { control }\end{array}$ & 10 & $\mathrm{I} / \mathrm{M}$ & $\begin{array}{l}0.5 \mathrm{ml} \\
\text { Sterile } \\
\text { broth }\end{array}$ & - & - & - \\
\hline $\begin{array}{r}4 \\
\text { control }\end{array}$ & 10 & $\mathrm{I} / \mathrm{P}$ & $\begin{array}{l}0.5 \mathrm{ml} \\
\text { Sterile } \\
\text { broth }\end{array}$ & - & - & - \\
\hline
\end{tabular}


Table 3 :Drugs sensitivity test of Aeromonas hydrophila isolated From Oreochromis niloticus .

\begin{tabular}{|l|c|}
\hline \multicolumn{1}{|c|}{ Drugs } & Reaction \\
\hline Oxytetracycline & +++ \\
Ampicillin & + \\
Stryptomycin & ++ \\
Penicillin & + \\
Neomycin & + \\
Sulphamerazine & +++ \\
Erythromycin & ++ \\
Chloramphinicol & ++ \\
\hline
\end{tabular}

+ Low sensitive

++ Moderate sensitive

+++ Highly sensitive 


\section{References}

Allan, B.J. and Stevenson, R .m . w.(1981 ) :

Extracellular virulence factors of Aeromonas hydrophila in fish Infection . Can . Microbial . 27:2224-1122

Amlacher , E .(1970):

Textbook of fish diseases . Water proof . Edition by D. A. onory and R. L. Herman , BYTT.F.H. Publications .

Bauer A. W.,Kurby W.M.M.,Sherris , J.C.and Turk M. (1966): Antibiotic susceptibility testing by a standardized single disc method Am. J.Clin. 45, 493-496 .

Bio-Merieus(1984):

Laboratory reagents and products . Bacteriology Ma. Cly.L Etoile 69260 . Charbonmiees les- Bains, France.

Boira, R.A. (1996):

Hydrophila group Aeromonads in environmental waters.

Culture ,17: 1-4

Brenden , R.A.and Huizinga , H.W. (1986) :

Pathogophysiology of expermintal Aeromonas hydrophila infection in gold fish . J. of fish disease , 9:163-167 .

Buchanan , R. L. and palumbo, S.A. (1985):

Aeromonas hydrophila and Aeromonas sorbia as potential food poisoning species : a review . J. food safety . $7:$ 15-29.

ColesN.W., Gilbo C.M.and Broas A.J.(1969) :

Purification, properties and mechanism of action of a staphyoltic enzyme produced by Aeromonas hydrophila . Biochem. J., 111, 7-15

Cruickshank , R. ; Duguid , J. P. Marmion, B. P. and Swain , R.H.(1975) :

Medical Microbiology.The practice of medicalmicrobiology $12^{\text {th }}$ ed.; vol. 11,Churcill living stone Edinburgh , London and New York . 
El-shaboury , F.A. (1998) :

Some studies on the Aeromonas infections of Brolus lake fish

(Oreochromis niloticus) in Kafr El-Sheikh province.

Alex. J. vet . science . vol . 14 No. 3 :105-115.

Essa, M.; Badran, A. and Moustafa, M. (1991) :

An outbreak of Redmouth disease among cultured fresh water fishes in Ismailia governorate . Alex . J. vet. Sci., vol. 6 and 7 109-118 .

Essa, M.E.; Aeulam , M. A. and El-Nimer, M.M.(1985):

Enzootic of fin rot among carp finger lings in Egyptian fish ponds

J.Egypt. vet. Med. Assoc ., 45 (1)83-93 .

Finegold,S.M. and Martin, W.J. (1982) :

Diagnostic Microbiology . $6{ }^{6}$ Ed. The C. V. Mos by company U.S.A.

Grizzle , J.M. and Kiryu, Y. (1993) :

Histopathplogy of gill, liver and pancreas and serum enzyme levels of channel catfish infected with Aeromonas hydrophila Complex . J . Aquat . Anim. Health 5 (No.1) :36-50 .

\section{Kanai, K. and Wakabayashi , H. (1984)}

Purification and some properties of protease from Aeromonas hydrophila. Bull. J. P N . Soc. Sci. fish. 50 : 1367-1374.

Kombanets, E. V. ; Isaeva, N. M. and Balakhnin, L.A. (1992) : Bacteria of the genus Aeromonas and their role in aqua culture . Mikrobial, Z. H. 54 (4):89-99 .

Kou, G. H. (1972):

Studies on the occurance and biochemical properties of virulent and avirulant strains of fresh water fish pathogen, Aeromonas liqueficens. J. fish. Soc. Taiwan ,(1),8-13 .

Lallier, R. Bernard, F. and Labonde, G.(1984) :

Difference in the extracellular products of two strains of Aeromonas hydrophila virulent and weakly virulent for fish .

Can. J. Microbiol. 30900-904 . 
Lehane,L. and Rawlin G. T.(2000):

Topically acquired bacterial zoonoses . Med. Of Asut. Sep.; 173

(5):256-259 .

Lennette E. H. Balows A., Hausler, W. J. and Traunt J. P. (1980):

Manual of clinical Microbiology . Amer.Soc. Micro., Washington

D. C., U.S.A.

McGary, D. J.; Kraxberger, T.; Alberts, V. A. ; Te-Strake.D. And Lime. D.And Lime. D.V. (1990):

Investigations of protential microbial pathogens associated with ulcerative disease syndrome of Florida fish .SAN DIEGO U.S.A. Academic-press pp. 65-75

Mayer F.P. (1970):

Seasonal fluctuations in the incidence of disease on fish farms.

In symposium on Diseases of fishes and shellfishes . S.F.

Snieszko(Eds.), special publication, No. 5, Washington, D.C.

American Fisheries Society, pp. 21-29.

Millership, S.E.; Curnow, S. R. and Chattopadhyay, B. (1983):

Faecal carriage rate of Aeromonas hydrophila

J. clin. Path. ; 36 (8) 920-923 .

Nagah, S.(1991):

Occurrence of Aeromonas hydrophila in raw milk .

Assuit. Vet. Med. J. vol. 25 No. 50 (98-102).

Neumann W. and Ploger W. (1975):

Antibiotic sensitivity tests on strains of Aeromonas isolated

From carp.DeutscheTirrarziliche Wochenshrift , 82 (2), 80-83

Norman (1988): Introduction to veterinary pathology . $1^{\text {st }}$. Ed. , Iowa state university press, U.S.A.P. 434-435.

\section{Ozbas,Z.Y.; vural, Hand Aytac, S.A.(1996):}

Combined effect of gamma-irradiation and conventional cooking on Aeromonas hydrophila in meat ball.

Zlebensm Unters Forsch, 202 (1) : 60-62. 
Picard, B.; Arlet, G. and Goullet, P. (1983) :

Water origin of Aeromonas hydrophila hospital infections .

Press Med.,12,(11) : $700-702$.

Popoff, M. and Veron, M. (1984) :

Aeromonas, P. 545-584. IN N. R. Kr ieg (ed).

Bergy's manual of systemic bacteriology, vol.1.

The Williams \& wilkins co. Baltimore .

Samaha, H. A. ; Haggag, Y. N. and Nadia Mahfouz . (2004) :

Brackish and marine water fish as a source of certain bacterial

Pathogen to human beings .

J. Alex. Vet . sci., $21: 238-248$.

Schaperelous, W. , Kullow, H. and Schrecken beck K. (1992):

Fish disease vol. (1) . Balkema A.A., Rotterdam .

Schneider R. and Nicholson B. L. (1980):

Bacteria associated with fin rot disease in hatchery reared

Atlantic Salmon (Salmo salar) . Can. J. fish. Aqua. Sci.,

73 (10), 1505-1513 .

Shahat, A.A. and HAMODA, E.E. (2000) :

Aeromonas septicaemia in Tilapia Nilotica cultured farm .

J. Egypt Vet. Med. Ass. $60: 139-145$.

Shotts, E.B.J R and Rimler, R. (1973) :

Medium for the isolation of Aeromonas hydrophila .

APP . Microbio Vol. 26. No. 4, P. 550-553.

\section{Snieszko S. F. and Bullock G.L.(1974) :}

Diseases of fresh water fishes caused by bacteria of the genus

Aeromonas, Pseudomonas and Vibrio . Fish Dis. Leaflet, 40.1-10 .

Soliman, M. K. (1988) :

The pathogenesis of Aeromonas hydrophila isolates in fish with special emphasis on their control . ph. D. thesis Fac. VBet. Med., university of Alexandria . 
Son, R.; Rusul, G.; Sahilab, A.M.; Zainuri, A.; Raha, A.R. and Salmuh. I.(1997) :

Antibiotic resistance and plasmid profile of Aeromonas hydrophila isolates from cultured fish . ( Tilapia Mossambica) . Lett. AppI. Mic. 24 (6) :479-482 .

Trust, T. J. and Sparrow, R.A.H. (1974) :

The bacterial flora in the alimentary tract of fresh water Salomid fishes . Can. J. Microbiol . 20 : 1219-1228 .

Wakabaysshi H. , Kanai K. , Hus T. U. and Egus S. (1981) :

Pathogenic activities of Aeromonas hydrophila biovar hydrophila ( Chester). Fish. Pathol. 15 (3 / 4 ), 319-325 . 


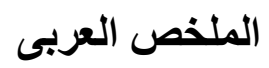

در اسات بكتريولوجية عن الاصابة ببكتريا الايروموناس لاسماك البلطى المستزر عة فى محافظة الاسكندرية

د/علا عبد العزيز محمد باشنا معهد بحوث صحة الحيوان فرع الاسكندرية

إثتنملت الدر اسة على فحص عدد . . 1 سمكة بلطى مريضة تم جمعها من مزارع

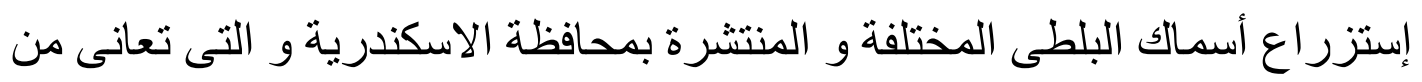
إصابات مرضية شديدة مع نسبة نفوق عالية .

و قد تم فحص الاسماك فحصا ظاهريا إكلينيكياو تم إجراء الصفات التشريحية ثم بعد ذللك تم الزرع و الفحص البكتريولوجى و كانت نتيجة الفحص البكتريولوجى

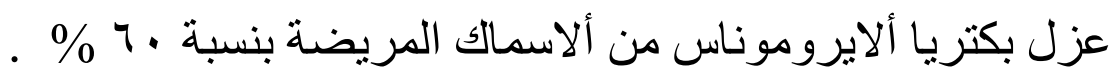

كما تم إعادة عزل هذه العتر ات من البكتريا بعد إجراء العدوى الصناعية فى المعل لاسماك بلطى سليمة و ذلك عن طريق الحقن العضلى و البريتونى .

$$
\text { و وجد أن الميكروب مرضى و قادر على إحداث العدوى . }
$$

هذا و قد تم إجر اء إختبار الحساسية الجرثومية للعتر ات المعزولة و وجد إنها حساسة للمضادات ألاوكسى تتر اسيكلين و السلفا مير ازين . ل 